\title{
Persepsi Masyarakat Kecamatan Penjaringan terhadap Kebijakan Pengelolaan Waduk Pluit
}

\section{Perception of Penjaringan District's Community Towards Policy of Pluit Reservoir Management}

\author{
Yosia BSMS Silalahi \\ Program Studi Ilmu Pengelolaan Sumberdaya Alam dan Lingkungan IPB University \\ e-mail: yosia_silalahi@yahoo.com \\ Iin Ichwandi \\ Program Studi Ilmu Pengelolaan Sumberdaya Alam dan Lingkungan IPB University \\ e-mail: iichwandi@yahoo.com \\ Sambas Basuni \\ Program Studi Ilmu Pengelolaan Sumberdaya Alam dan Lingkungan IPB University \\ e-mail: sambas_basuni@yahoo.com
}

\begin{abstract}
Pluit Reservoir has a big role in DKI Jakarta. Efforts to optimize the Pluit Resevour are facing various problems, such as silting the reservoir, water quality pollution, the existence of illegal settlements of the population, thus decreasing the function of the Pluit Reservoir as flood control and water resources. In an effort to overcome the problem, the government has mad normalization of reservoir policy. Information regarding the level of knowledge/ management of the Pluit Reservoir. The purpose of this study is to analyze the level of knowledgel perceptions of the community and managers on the functions, problems and management policies of the Pluit Reservoir, to analyze the attitudes of the community and managers towards the Pluit Reservoir management policy, to analyze the level of community and manager satisfaction with the Pluit Reservoir management policy. The analyze method is descriptive quantitative and qualitative methods using Likert scale and supply-demand analysis. The result showed that the level of knowledge/ perception of both managers and the community was still low on the program of land acquisition and relocation of flats, reservoir dredging programs, and waste cleaning and handling programs. The attitude of both the managers and the community is still low towards the land acquisition and relocation program to flats. The level of satisfaction that is still low both from managers and the community regarding land acquisition and relocation to flats and also with the reservoir dredging program.
\end{abstract}

Keywords: Attitudes, perception, likert, satisfaction, supply-demand analysis.

\section{ABSTRAK}

Waduk Pluit memiliki peran besar di DKI Jakarta. Upaya optimalisasi Waduk Pluit menghadapi berbagai permasalahan, seperti pendangkalan waduk, pencemaran kualitas air, adanya pemukiman liar penduduk, sehingga menurunnya fungsi Waduk Pluit sebagai pengendali banjir dan sumber daya air. Dalam upaya mengatasi permasalahan, pemerintah telah melakukan berbagai upaya diantaranya adalah normalisasi waduk. Informasi mengenai tingkat pengetahuan/ persepsi, sikap serta tingkat kepuasan masyarakat serta pengelola penting untuk dipertimbangkan dalam pengelolaan Waduk Pluit. Tujuan penelitian ini yaitu menganalisis tingkat pengetahuan/ persepsi masyarakat dan pengelola terhadap fungsi, masalah dan kebijakan pengelolaan Waduk Pluit, menganalisis sikap masyarakat dan pengelola terhadap kebijakan pengelolaan Waduk Pluit, menganalisis tingkat kepuasan masyarakat dan pengelola terhadap kebijakan pengelolaan Waduk Pluit. Metode analisis berupa metode deskripstif kuantitaf dan kualitatif dengan menggunakan skala likert dan analisis supply-demand. Hasil penelitian menunjukkan bahwa tingkat pengetahuan/ persepsi baik pengelola maupun masyarakat masih rendah pada program pembebasan lahan dan relokasi rumah susun, program pengerukan waduk, dan program pembersihan dan penanganan sampah. Sikap yang masih rendah baik dari pengelola maupun masyarakat terhadap program pembebasan lahan dan relokasi ke rumah susun. Tingkat kepuasan yang masih rendah baik dari pengelola maupun masyarakat terhadap pembebasan lahan dan relokasi ke rumah susun dan juga terhadap program pengerukan waduk.

Kata Kunci: Analisis supply-demand, likert, persepsi, sikap, tingkat kepuasan. 


\section{PENDAHULUAN}

Waduk Pluit merupakan salah satu waduk yang berada di Provinsi Daerah Khusus Ibukota (DKI) Jakarta. Fungsi utama Waduk Pluit sebagai penyerap air dan pengendali banjir, menjadikan Waduk Pluit memiliki peran yang paling besar dibandingkan dengan waduk lain di wilayah DKI Jakarta. Proyek pengelolaan Waduk Pluit dimulai sejak tahun 1960 yang ditandai dengan penetapan daerah Pluit sebagai kawasan tertutup dalam Keputusan Peperda Jakarta Raya dan Sekitarnya No 387/ Tahun 1960 (Dina, 2013). Namun pada tahun 1990, pemukiman liar penduduk di daerah tepi Waduk Pluit menekan luas hamparan sebesar 20 ha (Yukadar, 2014).

Permasalahan yang terjadi akibat adanya penyempitan lahan waduk oleh bangunan pemukiman liar penduduk, pemerintah DKI Jakarta kemudian melakukan upaya normalisasi Waduk Pluit melalui Perda No. 8 Tahun 2007 tentang ketertiban umum Kota DKI Jakarta. Dalam pasal 13 Perda tersebut menyebutkan bahwa setiap orang atau badan dilarang membangun tempat mandi cuci kakus, hunian/tempat tinggal atau tempat usaha di atas saluran sungai dan bantaran sungai serta di dalam kawasan setu, waduk dan danau. Selain mengeluarkan kebijakan melalui Perda No. 8 Tahun 2007, pemerintah DKI Jakarta telah melakukan upaya normalisasi fungsi Waduk Pluit pada tahun 2013 dengan cara merelokasi pemukiman liar di area tersebut ke beberapa rumah susun (Maharani et al., 2015).

Berdasarkan fungsinya sebagai pengendali banjir, kebijakan normalisasi Waduk Pluit tersebut belum sepenuhnya dapat menangani atau mencegah kejadian banjir di provinsi DKI Jakarta. Fungsi waduk pluit sebagai prasarana sumber daya air juga masih berada di luar kategori dapat dimanfaatkan. Penelitian yang dilakukan oleh Linne et al. (2015) menemukan bahwa kualitas air Waduk Pluit yang mendekati tercemar dan tidak layak dijadikan sebagai tempat kegiatan perikanan.

Berbagai kebijakan terkait pengelolaan Waduk Pluit telah diimplementasikan oleh Pemerintah Provinsi DKI Jakarta. Akan tetapi, upaya optimalisasi pemanfaatan Waduk Pluit menghadapi berbagai permasalahan. Permasalahan yang terjadi seperti pendangkalan, pencemaran kualitas air, dan aktivitas masyarakat sekitar waduk pluit sebagaimana yang telah diulas di atas, dapat memengaruhi kualitas Waduk Pluit.

Pemerintah telah berupaya melakukan berbagai kebijakan dalam pengelolaan Waduk Pluit. Beberapa program yang telah diupayakan dalam normalisasi fungsi Wdauk Pluit diantaranya : 1) Program pembebasan lahan dan relokasi masyarakat ke rumah susun, 2) Program pengerukan Waduk Pluit, 3) Program ruang terbuka hijau (RTH), 4) Program pembersihan sampah, dan 5) Program optimalisasi pompa-pompa air. Pemerintah bekerja sama dengan beberapa pengelola dalam menjalankan program-program normalisasi Waduk Pluit, diantaranya : 1) Dinas Perumahan dan Gedung Pemerintah Daerah Provinsi DKI Jakarta dalam melaksanakan program pembebasan lahan dan relokasi masyarakat ke rumah susun, serta program pembersihan sampah, 2) Dinas Sumber daya Air Provinsi DKI Jakarta dalam melaksanakan program pengerukan Waduk Pluit , 3) Jakpro dalam melaksanakan program taman kota/ ruang terbuka hijau (RTH), dan 4) Unit Pelaksana Kebersihan Badan Air Kecamatan Penjaringan dalam melaksanakan program optimalisasi pompa-pompa air. Namun pelaksanaan program-program normalisasi ini belum berjalan secara optimal sehingga perlu evaluasi bersama terkait pelaksanaan dan hasil dari program. Evaluasi ini dapat berasal dari persepsi masyarakat yang tinggal di sekitar Waduk Pluit. Selain persepsi masyarakat, persepsi dari pengelola juga penting untuk diketahui agar dapat diketahui kendala dalam pelaksanaannya. Persepsi yang berbeda dari setiap individu akan berpengaruh terhadap sikap yang ditunjukkan, sehingga dalam penelitian ini juga akan dilihat sikap masyarakat dan pengelola terhadap kebijakan normalisasi. Tingkat kepuasan juga menjadi salah satu indikator keberhasilan pelaksanaan kebijakan normalisasi Waduk Pluit.

Berdasarkan hal tersebut di atas, maka masalah yang akan dijawab dalam penelitian ini adalah sebagai berikut:

1. Bagaimana tingkat pengetahuan/persepsi masyarakat dan pengelola terhadap fungsi, masalah dan kebijakan pengelolaan Waduk Pluit?

2. Bagaimana sikap masyarakat dan pengelola terhadap kebijakan pengelolaan Waduk Pluit? 
3. Bagaimana tingkat kepuasan masyarakat dan penangung jawab terhadap kebijakan pengelolaan Waduk Pluit?

\section{Tinjauan Pustaka \\ Fungsi Waduk}

Waduk merupakan area tergenang air sepanjang tahun yang dibentuk atau dibangun atas rekayasa manusia (Kordi \& Tancung, 2007). Waduk dibuat setidaknya memberi ruang agar air dapat tergenang atau badan air yang memiliki ceruk, saluran masuk (inlet), saluran pengeluaran (outlet) dan berhubungan langsung dengan sungai utama yang mengairinya. Sebagai pengendali banjir, waduk berfungsi menahan semua atau sebagian air banjir dalam tampunganya dan mengalirkan sesuai dengan kapasitas sungai (Shaw et al., 2004). Dengan demikian, pembangunan waduk merupakan suatu upaya manusia dalam mengurangi kerugian yang disebabkan oleh air baik berupa banjir maupun kekeringan dengan memanfaatkan sumberdaya alam tersedia.

Sarwono (2007) dalam Ramli dan Yuwono (2015) mengungkapkan bahwa terdapat beberapa faktor yang mempengaruhi kinerja pengoperasian waduk secara efisien dan optimal berupa keadaan waduk, keadaan sosial, pengelolaan waduk, keadaan daerah aliran sungai (DAS), dan keadaan sumberdaya manusia. Keadaan waduk berupa fungsi waduk, jenis waduk, ukuran waduk, volume waduk, umur peralatan dan keamanan waduk. Keadaan sosial mencakup aspek pengoperasian, distribusi, peran masyarakat, adat istiadat, sosial ekonomi dan organisasi masyarakat. Pengelolaan waduk yang dimaksud berupa standar operasional perusahaan (SOP), kordinasi pengawasan, operator waduk, fasilitas kerja, operasi jangka pendek, menengah dan jangka panjang, kebijakan pengoperasian waduk dan metode operasi. Keadaan DAS berupa kondisi alam, lokasi waduk, bentuk DAS, tataguna lahan, debit inflow, fluktuasi muka air, sedimentasi, curah hujan, neraca air dan tata ruang. Sedangkan keadaan sumber daya manusia mencakup keterampiran, team kerja, motivasi kerja, produktivitas kerja dan pengelolaan.

\section{Pengelolaan dan Kebijakan Normalisasi Waduk Pluit}

Pengelolaan Waduk Pluit merupakan kebijakan Pemerintah Provinsi DKI Jakarta yang berdasarkan pada dokumen Rencana Tata Ruang Wilayah 2030 Pemerintah Provinsi DKI Jakarta (RTRW 2030 DKI Jakarta). Dalam dokumen tersebut, Waduk Pluit merupakan prasarana pengendalian daya rusak air sekaligus sebagai prasarana sumber daya air. Sebagai prasarana pengendalian daya rusak air, Waduk Pluit berada dalam area sistem polder pluit yang akan dikelola oleh pemerintah DKI Jakarta (Pemprov DKI Jakarta, 2012). Waduk Sistem polder merupakan suatu sistem yang secara hidrologis memisahkan wilayahnya dari sekelilingnya baik secara alamiah maupun buatan yang dilengkapi dengan tanggul, sistem drainase internal, pompa dan atau waduk serta pintu air. Sistem polder merupakan sistem yang membiarkan elevasi tanah asli, dan airnya diturunkan dengan pengontrolan menggunakan pompa dan tanggul atau manajemen lainnya (Suripin, 2004 dalam Yudi et al., 2017).

Upaya Normalisasi Waduk Pluit oleh pemerintah provinsi DKI Jakarta pada tahun 2013 dapat diartikan sebagai perbaikan kualitas waduk dalam mengendalikan banjir. Maharani et al. (2015) menjelaskan bahwa salah satu upaya yang dilakukan adalah dengan mengembalikan fungsi bantaran waduk sebagai ruang terbuka hijau yang berfungsi sebagai area resapan, penghuni pemukiman liar di area tersebut kemudian direlokasi ke beberapa rumah susun.

Implementasi kebijakan normalisasi waduk pluit masih menghadapi beberapa faktor penghambat. Hasil penelitian Yukadar (2014) mengungkapkan bahwa faktor penghambat tersebut berupa sumber daya finansial pendanaan normalisasi, sumberdaya material (bangunan rusun), dan dukungan publik terhadap kebijakan normalisasi waduk pluit. Dukungan publik sangatlah penting mengingat besarnya jumlah masyarakat yang bermukim dan beraktifitas di sekitar waduk pluit. Hal tersebut senada dengan penjelasan Fachrul et al. (2016) bahwa kualitas waduk pluit dipengaruhi oleh kondisi lingkungan sekitanya yang didominasi oleh kegiatan perdagangan, industri, jasa dan permukiman penduduk.

Pada saat ini, di bawah kepemimpinan Anies Baswedan sebagai Gubernur DKI Jakarta, pengelolaan waduk pluit dikelola oleh perangkat kerja Dinas Sumberdaya Air dan Dinas

pertamanan dan hutan kota. Pengelolaan Waduk Pluit dalam dokumen RPJMD Provinsi DKI 
Jakarta Tahun 2017-2022 berada dalam program kerja pembangunan waduk atau naturalisasi dan normalisasi sungai. Hal tersebut merupakan upaya meningkatkan kapasitas tampung air sehingga tidak meluap dan menggenangi wilayah di sekitar aliran air termasuk waduk. Sedangkan naturalisasi yang dimaksud adalah upaya pembenahan sungai dengan cara alamiah, dengan memperhatikan ekosistem dan lingkungan. Naturalisasi bertujuan untuk mengelola arus sungai agar air dapat meresap ke tanah di sepanjang perjalannya ke hilir, misalnya dengan mempertahankan kelokan sungai dan penetapan jalur hijau di sepanjang sungai (Pemprov DKI Jakarta, 2018).

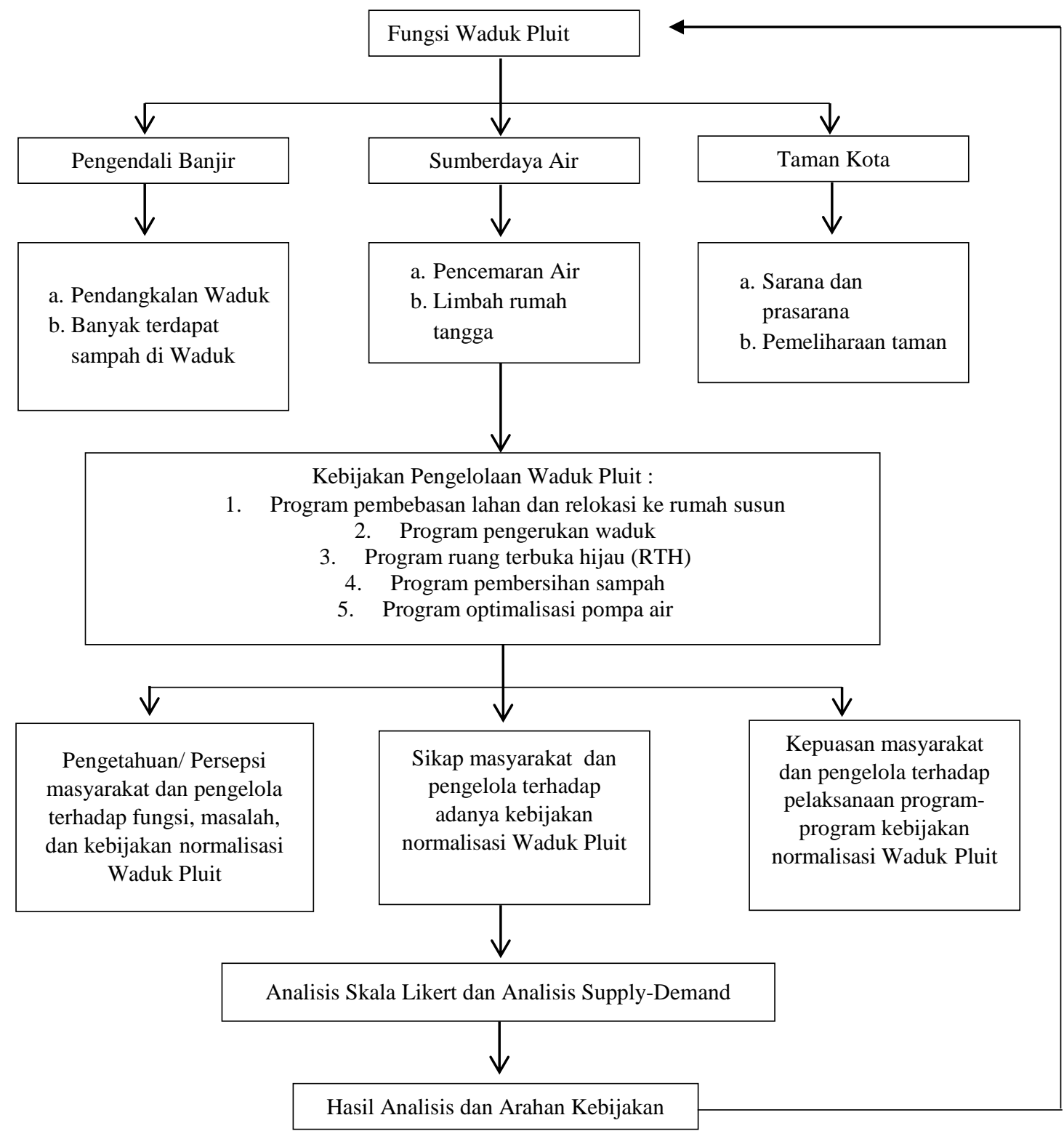

Gambar 1. Kerangka Pemikiran Penelitian

\section{METODE PENELITIAN}

Penelitian ini menggunakan survei kuesioner yang dianalisis dengan menggunakan analisis kuantitatif dan kualitatif. Analisis kuantitatif digunakan untuk mendapatkan skor terhadap tingkat pengetahuan/ persepsi, sikap dan tingkat kepuasan masyarakat dan pengelola terhadap kebijakan normalisasi Waduk Pluit. Analisis kualitatif digunakan untuk mendeskripsikan hasil dari 
pengetahuan/ persepsi, sikap dan tingkat kepuasan masyarakat dan pengelola terhadap kebijakan normalisasi Waduk Pluit.

\section{Lokasi dan Waktu Penelitian}

Penelitian ini dilaksanakan di lingkungan masyarakat yang terkena dampak langsung dari keberadaan Waduk Pluit yaitu di Kecamatan Penjaringan, Provinsi DKI Jakarta. Pengambilan data dilaksanakan selama dua bulan.

\section{Jenis data dan Pengumpulan data}

Data yang dikumpulkan dalam penelitian ini terdiri data primer dan sekunder. Pengumpulan data dilakukan melalui:

1. Wawancara menggunakan kuesioner

Wawancara menggunakan kuesioner digunakan untuk mengumpulkan data tentang informasi pribadi responden, pengetahuan/ persepsi, sikap dan kepuasan masyarakat terkait fungsi dan masalah Waduk Pluit serta kebijakan dan program normalisasi dalam pengelolaan Waduk Pluit.

Pemilihan responden penelitian menggunakan teknik purposive sampling, yaitu teknik penentuan sampel dengan pertimbangan tertentu (Sugiono, 2015). Pertimbangan pemilihan responden adalah sebagai berikut:

a. Masyarakat Kecamatan Penjaringan yang dibagi menjadi tiga kelompok responden yaitu : 1) masyarakat yang masih bermukim di bantaran Waduk Pluit, 2) masyarakat yang sudah relokasi atau pindah ke rusun, dan 3) masyarakat lain sekitar Waduk Pluit yang tidak termasuk pada kelompok 1) dan 2). Pembagian kelompok ini bertujuan agar data dan informasi yang didapatkan berasal dari setiap kelompok masyarakat tersebut.

b. Jumlah Responden yang dipilih sebanyak $58 \mathrm{KK}$ yang berasal dari masing-masing kelompok responden.

c. Selain masyarakat, responden juga adalah pengelola Waduk Pluit diantaranya: Dinas Sumber Daya Air Provinsi DKI Jakarta, UPK Badan Air Waduk Pluit, Pengelola program relokasi, dan Jakpro sebagai pengelola taman kota Waduk Pluit.

3. Observasi lapang

Observasi lapang dilakukan untuk memverifikasi data yang didapat melalui studi literatur dan wawancara dengan kondisi di lapangan, sehingga dapat dijadikan pembanding untuk memperkuat data yang didapatkan.

4. Studi pustaka

Studi pustaka dilakukan untuk mendapatkan data meliputi letak geografis, keadaan sosial ekonomi masyarakat Kelurahan Penjaringan dan Kelurahan Pluit, struktur organisasi pengelola Waduk Pluit, data demografi, dan riwayat pengelolaan Waduk Pluit. Pustaka yang digunakan berupa dokumen atau publikasi mengenai Waduk Pluit yang dapat dipertanggungjawabkan.

\section{Prosedur Analisis Data}

Tingkat pengetahuan/ persepsi masyarakat dan pengelola terhadap fungsi, masalah, dan kebijakan pengelolaan Waduk Pluit

Analisis tingkat pengetahuan/persepsi masyarakat dan pengelola terhadap fungsi, masalah, dan kebijakan pengelolaan Waduk Pluit menggunakan bantuan skoring. Penentuan skor dilakukan dengan menggunakan Skala Likert. Proses pengukuran dilakukan berdasarkan jawaban responden atas pertanyaan yang diberikan. Setiap responden akan dimintai jawaban "tidak mengetahui" "kurang mengetahui", "cukup mengetahui", "mengetahui", "sangat mengetahui". Jawaban-jawaban ini diberi skors 1, 2, 3, 4, 5 secara berurutan. Skor dari jawaban yang telah diperoleh dari responden akan diubah kedalam bentuk skala. Skala ditentukan terlebih dahulu dengan mencari nilai intervalnya dengan menggunakan perhitungan sebagai berikut:

Interval $=\frac{\text { Bobot nilai tertinggi-Bobot nilai terendah }}{\text { Banyaknya kelas }}=\frac{5-1}{5}=0.8$ 
Besarnya nilai interval yang telah diketahui, kemudian dibuat skala untuk mengetahui tingkatan pengetahuan/ persepsi, sehingga dapat diketahui dimana letak penilaian responden terhadap setiap unsur. Skala tingkatan pengetahuan/persepsi dapat dilihat di Tabel 1.

Tabel 1. Tingkat pengetahuan/ persepsi masyarakat terhadap fungsi, masalah, dan kebijakan pengelolaan Waduk Pluit

\begin{tabular}{cc}
\hline Interval Nilai Tanggapan & Tingkat Pengetahuan/ Persepsi \\
\hline $4,21-5,00$ & Sangat Tahu \\
$3,41-4,20$ & Tahu \\
$2,61-3,40$ & Cukup Tahu \\
$1,81-2,60$ & Kurang Tahu \\
$1,00-1,80$ & Tidak Tahu \\
\hline
\end{tabular}

\section{Sikap masyarakat dan pengelola terhadap Kebijakan Pengelolaan Waduk Pluit}

Analisis sikap masyarakat dan pengelola terhadap kebijakan normalisasi Waduk Pluit menggunakan bantuan skoring. Penentuan skor dilakukan dengan menggunakan Skala Likert. Proses pengukuran dilakukan berdasarkan jawaban responden atas pertanyaan yang diberikan. Setiap responden akan dimintai jawaban "tidak setuju", "kurang setuju"“cukup setuju", "setuju", "sangat setuju". Jawaban-jawaban ini diberi skors 1, 2, 3, 4, 5 secara berurutan. Skor dari jawaban yang telah diperoleh dari responden akan diubah kedalam bentuk skala. Skala ditentukan terlebih dahulu dengan mencari nilai intervalnya dengan menggunakan perhitungan sebagai berikut:

$$
\text { Interval }=\frac{\text { Bobot nilai tertinggi }- \text { Bobot nilai terendah }}{\text { Banyaknya kelas }}=\frac{5-1}{5}=0.8
$$

Besarnya nilai interval yang telah diketahui, kemudian dibuat skala untuk mengetahui tingkatan sikap, sehingga dapat diketahui dimana letak penilaian responden terhadap setiap unsur. Skala tingkatan sikap dapat dilihat di Tabel 2.

Tabel 2. Sikap masyarakat dan pengelola terhadap kebijakan Normalisasi Waduk Pluit

\begin{tabular}{cc}
\hline Interval Nilai Tanggapan & Tingkat Sikap \\
\hline $4,21-5,00$ & Sangat Setuju \\
$3,41-4,20$ & Setuju \\
$2,61-3,40$ & Cukup Setuju \\
$1,81-2,60$ & Kurang Setuju \\
$1,00-1,80$ & Tidak Setuju \\
\hline
\end{tabular}

\section{Kepuasan masyarakat dan pengelola terhadap Kebijakan Pengelolaan Waduk Pluit}

Analisis kepuasan masyarakat dan pengelola terhadap kebijakan normalisasi Waduk Pluit menggunakan bantuan skoring. Penentuan skor dilakukan dengan menggunakan Skala Likert. Proses pengukuran dilakukan berdasarkan jawaban responden atas pertanyaan yang diberikan. Setiap responden akan dimintai jawaban "tidak puas", "kurang puas" "cukup puas", "puas", dan"sangat puas". Jawaban-jawaban ini diberi skors 1, 2, 3, 4, 5 secara berurutan. Skor dari jawaban yang telah diperoleh dari responden akan diubah kedalam bentuk skala. Skala ditentukan terlebih dahulu dengan mencari nilai intervalnya dengan menggunakan perhitungan sebagai berikut:

$$
\text { Interval }=\frac{\text { Bobot nilai tertinggi }- \text { Bobot nilai terendah }}{\text { Banyaknya kelas }}=\frac{5-1}{5}=0.8
$$

Besarnya nilai interval yang telah diketahui, kemudian dibuat skala untuk mengetahui tingkatan kepuasan, sehingga dapat diketahui dimana letak penilaian responden terhadap setiap unsur. Skala tingkatan sikap dapat dilihat di Tabel 3. 
Tabel 3. Tingkat kepuasan masyarakat dan pengelola terhadap kebijakan Normalisasi Waduk Pluit

\begin{tabular}{cc}
\hline Interval Nilai Tanggapan & Tingkat Kepuasan \\
\hline $4,21-5,00$ & Sangat Puas \\
$3,41-4,20$ & Puas \\
$2,61-3,40$ & Cukup Puas \\
$1,81-2,60$ & Kurang Puas \\
$1,00-1,80$ & Tidak Puas \\
\hline
\end{tabular}

\section{Analisis Supply-Demand dalam Kebijakan Pengelolaan Waduk Pluit}

Dalam analisis supply-demand, akan dilihat bagaimana pelaksanaan program-program normalisasi melalui Gambar di bawah, dimana sumbu Y menjadi unsur supply yaitu tingkat pengetahuan, sikap, maupun tingkat kepuasan pengelola yang melakukan program pengelolaan normalisasi Waduk Pluit dan sumbu X menjadi unsur demand yaitu tingkat pengetahuan, sikap, maupun tingkat kepuasan masyarakat yang menjadi sasaran dalam pelaksanaan program pengelolaan normalisasi Waduk Pluit.

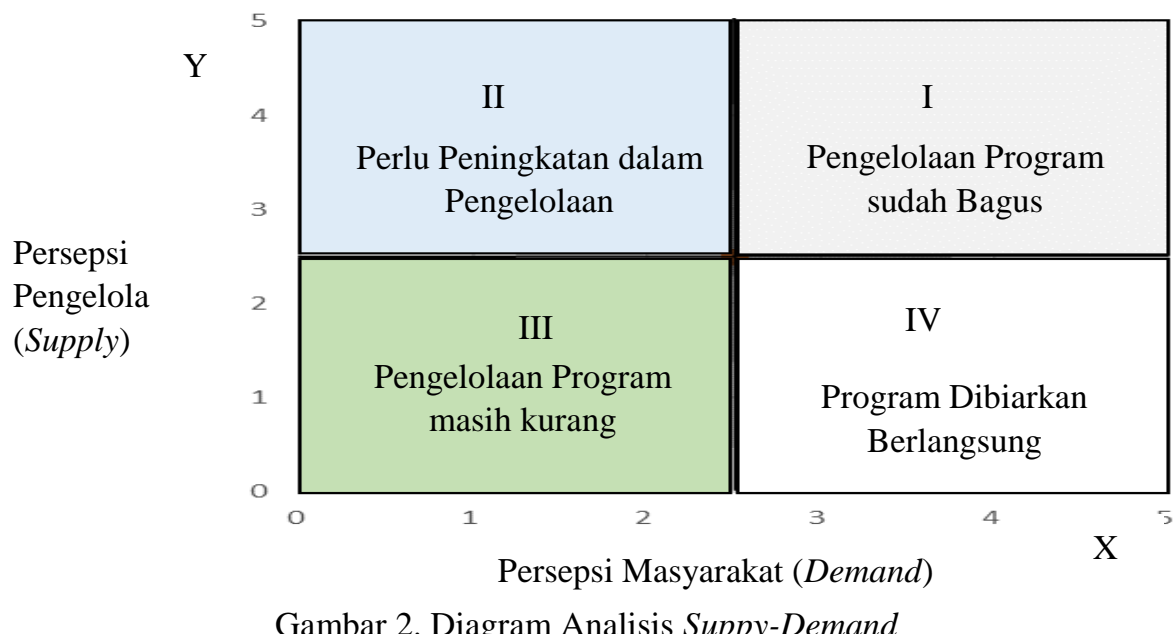

\section{HASIL DAN PEMBAHASAN}

\section{Kebijakan dan Program Pengelolaan Waduk Pluit}

Pengelolaan Waduk Pluit merupakan kebijakan Pemerintah Provinsi DKI Jakarta yang berdasarkan pada dokumen Rencana Tata Ruang Wilayah 2030 Pemerintah Provinsi DKI Jakarta (RTRW 2030 DKI Jakarta). Dalam dokumen tersebut, Waduk Pluit merupakan prasarana pengendalian daya rusak air sekaligus sebagai prasarana sumber daya air. Sebagai prasarana pengendalian daya rusak air, Waduk Pluit berada dalam area sistem polder pluit yang akan dikelola oleh pemerintah DKI Jakarta (Pemprov DKI Jakarta, 2012).

Pemerintah Provinsi DKI Jakarta melakukan kebijakan normalisasi Waduk Pluit berdasarkan wewenang Pemerintah Daerah dalam menerbitkan Rencana Tata Ruang Wilayah yang tercantum dalam Peraturan Daerah Nomor 1 Tahun 2012 tentang Rencana Tata Ruang Wilayah sampai dengan tahun 2030 (Perda No.1/2012). Berdasarkan Perda No.1/2012 dinyatakan untuk mencapai tujuan penataan ruang daerah dilakukan kebijakan diantaranya adalah normalisasi waduk.

Kewenangan pengelolaan Waduk Pluit berada di bawah pemerintahan Provinsi DKI Jakarta. Beberapa pengelola yang ditugasi dalam pengelolaan Waduk Pluit, terutama yang berkaitan dengan kebijakan normalisasi Waduk Pluit diantaranya :

1) Dinas Perumahan dan Gedung Pemerintah Daerah Provinsi DKI Jakarta dalam melaksanakan program pembebasan lahan dan relokasi masyarakat ke rumah susun, dan penanganan sampah di rumah susun, 
2) Dinas Sumber daya Air Provinsi DKI Jakarta dalam melaksanakan program pengerukan Waduk Pluit ,

3) PT. Jakpro dalam melaksanakan program taman kota/ ruang terbuka hijau (RTH), dan

4) Unit Pelaksana Kebersihan Badan Air Kecamatan Penjaringan dalam melaksanakan program optimalisasi pompa-pompa air.

Informasi mengenai program dan kegiatan yang dilakukan dalam kebijakan pengelolaan Waduk Pluit didapatkan berdasarkan wawancara terbuka terhadap para pengelola Waduk Pluit. Bagian tulisan ini akan menjabarkan beberapa hal terkait kegiatan pengelolaan Waduk Pluit yang terdiri dari : 1). Pihak Pengelola yang terlibat dalam normalisasi Waduk Pluit, 2). Program dan kegiatan yang terdapat dalam pengelolaan Waduk Pluit, 3). Progress pelaksanaan program dan kegiatan pengelolaan Waduk Pluit, 4) Hambatan yang terjadi pada pelaksanaan program dan kegiatan pengelolaan Waduk Pluit, 5) Saran bagi pelaksanaan program dan kegiatan pengelolaan Waduk Pluit. Penjelasan program-program normalisasi Waduk Pluit berdasarkan pihak pengelola dijabarkan sebagai berikut :

\section{Dinas Perumahan dan Gedung Pemerintah Daerah DKI Jakarta}

Pata tahun 2013, Pemprov DKI Jakarta di bawah kepemimpinan Gubernur DKI Joko Widodo berencana mengembalikan fungsi waduk Pluit seperti semula. Upaya yang dilakukan pemerintah tersebut adalah dengan melakukan penertiban terhadap permukiman illegal di bantaran Waduk Pluit. Hal ini dilakukan agar waduk dapat menampung air di saat musim hujan melanda wilayah DKI Jakarta. Dalam melakukan penertiban permukiman warga, Gubernur DKI Jakarta Joko Widodo, sebelumnya telah melakukan negosiasi, sosialisasi, dan himbauan kepada warga waduk Pluit terlebih dahulu, sebelum di lakukan penggusuran dan memberikan solusi dengan merelokasi warga waduk Pluit ke Rusun Marunda Cilincing Jakarta Utara.

Berdasarkan RPJMD Prov DKI Jakarta Tahun 2017-2022, tujuan 1 yaitu mewujudkan kota Jakarta yang aman, tertib, dan kondusif, maka pemerintah melanjutkan program normalisasi Waduk Pluit. Berdasarkan hal tersebut, program/ kegiatan normalisasi Waduk Pluit di bawah pengelolaan Dinas Perumahan dan Gedung Pemerintah Daerah DKI Jakarta sebagai berikut:

1. Penertiban hunian/ pembebasan lahan warga Waduk Pluit

2. Relokasi warga Waduk Pluit ke rumah susun

Relokasi warga waduk Pluit tersebar di rusun wilayah DKI Jakarta, diantaranya relokasi ke Rusun Marunda Cilincing Jakarta Utara juga relokasi ke Rusun Tambora Jakarta Barat. Relokasi dilakukan setelah musibah banjir melanda kawasan sekitar Waduk Pluit. Relokasi ini tidak akan memberatkan warga waduk Pluit karena rusun-rusun yang disediakan merupakan subsidi dari Pemerintah. Di rumah susun akan di atur agar warga waduk Pluit lebih baik hidupnya sehingga tidak tinggal di tempat yang tidak layak. Selain itu akan tersedia pelayanan kesehatan puskesmas dan pasar. Pemerintah berencana untuk merelokasi seluruh warga di bantaran Waduk Pluit dan memberikan penghidupan yang lebih baik bagi warga Waduk Pluit.

Dalam hal ini, pengelolaan terkait relokasi warga berada di bawah tanggung jawab Unit Pelayanan Rumah Susun (UPRS), Dinas Perumahan dan Gedung Pemerintah Daerah Provinsi DKI Jakarta. Berdasarkan informasi yang didapatkan dari UPRS, terdapat beberapa kegiatan pendukung yang dilakukan pemerintah dalam upaya memberikan penghidupan yang layak bagi warga yang direlokasi, diantaranya:

\section{1). Housing carier}

Kegiatan housing carier ini dimulai sejak tahun 2019. Target dari kegiatan housing carier ini adalah para warga Waduk Pluit dapat segera menempati rumah susun dengan status hak milik. Beberapa hal yang dilakukan dalam upaya pencapaian target tersebut diantaranya : pembangunan rumah susun, pembentukan dan pengangkatan Perhimpunan Pemilik dan Penghuni Satuan Rumah susun (P3SRS), dan mencari peminat rumah susun. Pendanaan terkait kegiatan housing carier ini 
2) Pembentukan bank sampah di rumah susun

Kegiatan ini dimulai tahun 2019, target dari kegiatan ini adalah adanya pengurangan volume sampah yang dibuang ke TPS Bantar Gebang. Pendanaan terkait kegiatan bank sampah berasal dari APBD DKI Jakarta dan juga CSR perusahaan. Secara keseluruhan, kendala yang dihadapi UPRS dalam mengelola rumah susun sebagai bagian dari kebijakan reloaksi warga Waduk Pluit yaitu masih terdapat "mafia" dalam rumah susun, sehingga pengelolaan diambil alih "mafia" tersebut, dan banyak masyarakat yang bukan haknay menempati rusun tersebut. Selain itu, belum adanya transparansi anggaran yang diberikan oleh pemerintah, sehingga dalam pengelolaan rusun, UPRS beberapa kali mengeluarkan biaya pribadi dalam memelihara dan merawat fasilitas rusun yang sudah rusak. Hal ini jelas memberatkan kinerja UPRS.

UPRS sebagai pengelola rusun dari program relokasi warga Waduk Pluit berharap bahwa pemerintah dapat memaksimalkan pemberdayaan masyarakat supaya masyarakat lebih aktif berpartisipasi dalam menjaga ketentraman dan ketertiban di rumah susun. Hal lain yang diharapkan oleh UPRS adalah warga dapat memanfaatkan rusun sebagai tempat tinggal yang lebih baik dari permukiman ilegal di bantaran Waduk Pluit, sehingga warga mendapatkan penghidupan yang lebih baik, dan Waduk Pluit dapat kembali berfungsi optimal.

\section{Dinas Sumber Daya Air Provinsi DKI Jakarta}

Dinas Sumber daya Air Provinsi DKI Jakarta merupakan salah satu pengelola/ pengelola yang ditugasi pemerintah pusat DKI Jakarta untuk melakukan beberapa program dalam upaya normalisasi Waduk Pluit. Beberapa program/ kegiatan normalisasi Waduk Pluit yang dilakukan oleh Dinas Sumber daya Air Provinsi DKI Jakarta, yaitu:

1) Kegiatan pengerukan waduk

Program pengerukan waduk yang berada di bawah tanggung jawab Dinas Sumber daya Air Provinsi DKI Jakarta merupakan kegiatan pemeliharaan yang dilakukan dalam upaya menjaga fungsi Waduk Pluit berjalan optimal. Kegiatan pengerukan waduk dilakukan untuk memaksimalkan daya tampung Waduk Pluit.

2) Kegiatan pemeliharaan pompa air

Selain program pengerukan waduk, Dinas Sumber daya Air Provinsi DKI Jakarta juga bertugas untuk mengelola program optimalisasi fungsi pompa-pompa air di Waduk Pluit. Pemeliharaan pompa air waduk dilakukan agar pompa air dapat bekerja secara optimal. Hal ini merupakan salah satu program jangka pendek yang dapat dilakukan pemerintah dalam upaya normalisasi waduk.

Pompa air digunakan untuk mengalirkan air banjir ke laut atau sungai. Pompa air ayng dimiliki Pemprov DKI Jakarta sebanyak 400 pompa stasioner dan 133 pompa mobile yang tersebar di 140 lokasi. Diharapkan pompa-pompa ini dapat berfungsi dengan maksimal selama musim penghujan. Pemerintah mengalokasikan anggaran untuk pengelolaan rumah pompa dalam APBD DKI 2020 sebesar Rp 106,44 miliar dari total anggaran untuk pengendalian banjir sebesar Rp 1,48 triliun. Peruntukan anggaran ini diantaranya pengelolaan pompa stasioner, pompa mobile, pintu air, bangunan rumah pompa serta rumah jaga dan kelengkapannya sistem aliran tengah, timur maupun barat.

3) Kegiatan operasional tahunan

Kegiatan operasional tahunan merupakan kegiatan operasional lain yang dilakukan oleh Dinas Sumber Daya Air dalam menjalankan fungsinya. Salah satu kegiatan opearsional tahunan adalah penggajian petugas pompa yang emmang sudah dianggarkan secara rutin.

\section{PT Jakpro (Jakarta Propertindo)}

Salah satu program/ kegiatan dalam kebijakan normalisasi Waduk Pluit yaitu membangun ruang terbuka hijau (RTH) di wilayah Waduk Pluit. Berdasarkan hal ini, pemerintah provinsi DKI Jakarta menjadikan sebagian wilayah Waduk Pluit menjadi taman kota. Sebagai salah satu Badan Usaha Milik Daerah (BUMD) Provinsi DKI Jakarta, PT Jakpro diresmikan oleh Gubernur Joko Widodo pada saat itu sebagai pengelola dan pengelola taman Waduk Pluit. Potensi luas taman Waduk Pluit adalah 10 hektar, dengan 4 hektar peruntukkannya sebagai ruang rekreasi publik. 
Selain untuk tempat rekreasi publi, wilayah taman kota juga dijadikan sebagai tempat instalasi pengelolaan limbah (IPAL) dan ruang untuk pedagang kaki lima (PKL).

Dalam menjalankan tugas pengelolaan taman waduk, beberapa kegiatan yang dilakukan oleh PT Jakpro diantaranya adalah membersihkan taman dan sekitar jalan di atas wilayah Waduk Pluit, juga mengelola parkiran. Sesuai dengan fungsi keberadaannya sebagai BUMD, maka kinerja PT Jakpro berorientasi pada keuntungan.Beberapa kendala yang dihadapi PT Jakpro dalam melakukan pengelolaan taman waduk yaitu adanya biaya operasional yang relatif besar. Diharapkan dalam pengelolaan taman Waduk Pluit dapat segera berpindah menjadi tanggung jawab Dinas Pertamanan dan Pemakaman Prov DKI Jakarta.

\section{Unit Pelaksana Kebersihan (UPK) Badan Air Kecamatan Penjaringan}

Unit Pelaksana Kebersihan (UPK) Badan Air Kecamatan Penjaringan berada di bawah Dinas Lingkungan Hidup Prov DKI Jakarta. Beberapa kegiatan pengelolaan dalam menunjang normalisasi Waduk Pluit telah ditetapkan oleh Gubernur DKI Jakarta melalui kewenangan Dinas Lingkungan Hidup. Kegiatan tersebut, yang berada di bawah tugas UPK Badan Air diantaranya :

1) Kegiatan penanganan sampah di waduk

Kegiatan penanganan sampah di waduk dilakukan sinergi dalam upaya untuk mengatasi pendangkalan yang terjadi di Waduk Pluit. Waduk Pluit seharusnya memiliki kedalaman 10 meter, namun jika sudah terjadi pendangkalan dan tergenangi sampah kedalamannya hanya mencapai tiga meter. Hal ini harus diatasi dalam upaya normalisasi fungsi waduk. Kegiatan ini sudah mulai dilakukan oleh UPK Badan Air sejak tahun 2015. Pendanaan berasal dari APBD DKI Jakarta. Targetnya kegiatan ini adalah tidak adanya lagi sampah di waduk atau kali.

2) Kegiatan pengurangan dan pengelolaan sampah organik dan anorganik

Selain melakukan penanganan sampah di waduk, UPK Badan Air juga memiliki kegiatan lain yaitu melakukan pengurangan dan pengelolaan sampah. Kegiatan ini sudah mulai dilakukan oleh UPK Badan Air sejak tahun 2019. Pendanaan berasal dari APBD DKI Jakarta. Targetnya kegiatan ini adalah masyarakat dapat melakukan pengurangan sampah mulai dari sumbernya.

Kegiatan ini dilakukan dengan adanya pemilahan sampah organik dan sampah anorganik.

Dalam menjalankan tugasnya sebagai salah satu pengelola kebijakan normalisasi Waduk Pluit, selain kegiatan yang sudah dijelaskan sebelumnya, UPK berharap dapat melakukan penanaman di bantaran waduk. Hal ini guna dapat menjaga ketahanan bantaran waduk karena adanya resapan air dari tanaman yang ditanaman di bantaran. Namun demikian, kegiatan ini belum dapat terlaksana.

\section{Hasil Analisis dan Arahan Kebijakan}

Hasil analisis dapat digunakan untuk mengetahui arah kebijakan yang dapat diambil guna meningkatkan pengelolaan waduk, agar Waduk Pluit dapat berfungsi secara optimal.

Tabel 4. Tingkat Pengetahuan/persepsi, Sikap, dan Kepuasan Masyarakat dan Pengelola Kebijakan Pengelolaan Waduk Pluit

\begin{tabular}{|c|c|c|c|c|}
\hline \multirow[b]{2}{*}{ Rincian } & \multicolumn{2}{|c|}{ Masyarakat } & \multicolumn{2}{|c|}{ Pengelola } \\
\hline & $\begin{array}{l}\text { Rata-Rata } \\
\text { Skor }\end{array}$ & Kategori & $\begin{array}{l}\text { Rata-Rata } \\
\text { Skor }\end{array}$ & Kategori \\
\hline $\begin{array}{l}\text { Tingkat Pengetahuan/ persepsi terhadap fungsi } \\
\text { Waduk Pluit }\end{array}$ & 3,31 & $\begin{array}{l}\text { Cukup } \\
\text { Tahu }\end{array}$ & 3,00 & $\begin{array}{l}\text { Cukup } \\
\text { Tahu }\end{array}$ \\
\hline $\begin{array}{l}\text { Tingkat Pengetahuan/ persepsi terhadap Masalah } \\
\text { Waduk }\end{array}$ & 3,52 & Tahu & 4,00 & Tahu \\
\hline $\begin{array}{l}\text { Tingkat Pengetahuan/ persepsi terhadap isi dan } \\
\text { transparansi program pengelolaan Waduk Pluit }\end{array}$ & 3,18 & $\begin{array}{c}\text { Cukup } \\
\text { Tahu }\end{array}$ & 2,98 & $\begin{array}{c}\text { Cukup } \\
\text { Tahu }\end{array}$ \\
\hline $\begin{array}{l}\text { Sikap terhadap isi dan transparansi program } \\
\text { pengelolaan Waduk Pluit }\end{array}$ & 3,70 & Setuju & 3,94 & Setuju \\
\hline $\begin{array}{l}\text { Sikap terhadap dukungan kebijakan pengelolaan } \\
\text { Waduk Pluit }\end{array}$ & 4,02 & Setuju & 4,11 & Setuju \\
\hline $\begin{array}{l}\text { Tingkat kepuasan terhadap kebijakan } \\
\text { pengelolaan Waduk Pluit }\end{array}$ & 4,12 & Puas & 3,52 & Puas \\
\hline
\end{tabular}


Berdasarkan hasil penelitian, diketahui bahwa tingkat pengetahuan masyarakat terhadap fungsi Waduk Pluit cukup mengetahui, begitu juga dengan program-program yang dilakukan dalam upaya normalisasi. Masyarakat mengetahui masalah yang terdapat di Waduk Pluit. Tingkat pengetahuan masyarakat terhadap masalah waduk relatif lebih tinggi dibandingkan tingkat pengetahuan masyarakat terhadap fungsi waduk. Hal ini menunjukkan bahwa, masalah yang terdapat di Waduk Pluit masih terlihat dan dirasakan lebih besar dibandingkan dengan upayaupaya yang dilakukan pemerintah dalam upaya normalisasi waduk sehingga fungsi waduk pun tidak cukup terlihat dan terasa oleh masyarakat.

Dari segi pengelola, diketahui bahwa tingkat pengetahuan pengelola terhadap fungsi Waduk Pluit yaitu cukup mengetahui, begitu juga dengan program-program yang dilakukan dalam upaya normalisasi. Namun mengetahui masalah yang terdapat di Waduk Pluit. Sama hal nya dengan tingkat pengetahuan masyarakat, hal ini menunjukkan bahwa, masalah yang terdapat di Waduk Pluit masih terlihat dan dirasakan lebih besar dibandingkan dengan upaya-upaya yang dilakukan pemerintah dalam upaya normalisasi waduk sehingga fungsi waduk pun tidak cukup terlihat dan terasa oleh bahkan oleh pengelola.

Berdasarkan hasil penelitian yang terdapat pada Tabel di atas, diketahui bahwa sikap yang ditunjukkan oleh masyarakat terhadap program-program yang dilakukan dalam upaya normalisasi sangat positif, hal ini terlihat dari sikap dan dukungan yang diberikan yaitu setuju dengan program-program yang diupayakan. Dari segi pengelola, diketahui bahwa sikap yang ditunjukkan oleh pengelola terhadap program-program yang dilakukan dalam upaya normalisasi sangat positif, hal ini terlihat dari sikap dan dukungan yang diberikan yaitu setuju dengan programprogram yang diupayakan. Hal ini menunjukkan bahwa para pengelola Waduk Pluit mendukung upaya normalisasi Waduk Pluit agar dapat menjalankan fungsinya secara optimal. Oleh sebab itu, peran dan keterlibatan semua stakeholder dibutuhkan agar tercapai tujuan dan target dari pelaksanaan program.

Secara keseluruhan, baik masyarakat maupun pengelola merasa puas dengan pelaksanaan program-program normalisasi Waduk Pluit. Namun hal ini tidak menjadikan kinerja pengelolaan waduk cukup dengan pencapaian yang sekarang, tetapi harus tetap dioptimalkan.

Tingkat Pengetahuan/ Persepsi terhadap Program Pengelolaan Waduk Pluit

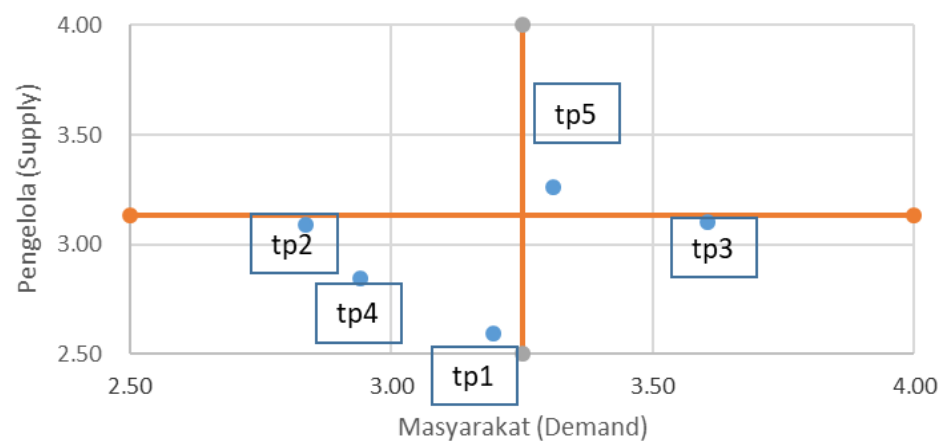

Gambar 3. Analisis Demand-Supply terhadap Tingkat Pengetahuan/ Persepsi

"Tingkat Pengetahuan/ persepsi terhadap isi dan transparansi program optimalisasi pompa air" berada pada kuadran I, artinya pelaksanaan program ini sudah berjalan dengan baik bagi pengelola dan memberikan dampak positif terhadap masyarakat. Program ini memiliki pelaksanaan yang baik, sehingga perlu dipertahankan dalam pelaksanaannya. Tidak ada hasil yang menunjukkan berada pada kuadran II. Pada kuadran III, terdapat "Tingkat Pengetahuan/ persepsi terhadap isi dan transparansi program pembebasan lahan dan relokasi rumah susun", "Tingkat Pengetahuan/ persepsi terhadap isi dan transparansi program pengerukan waduk", "Tingkat Pengetahuan/ persepsi terhadap isi dan transparansi program pembersihan dan penanganan sampah", artinya untuk ketiga program ini pelaksanannya belum berjalan dengan 
baik, dan belum terlalu diperhatikan oleh pengelola. "Tingkat Pengetahuan/ persepsi terhadap isi dan transparansi program taman kota" berada pada kuadran IV, artinya program ini dapat terus dijalankan karena masyarakat mengetahui isi dan pelaksanaan program tersebut.

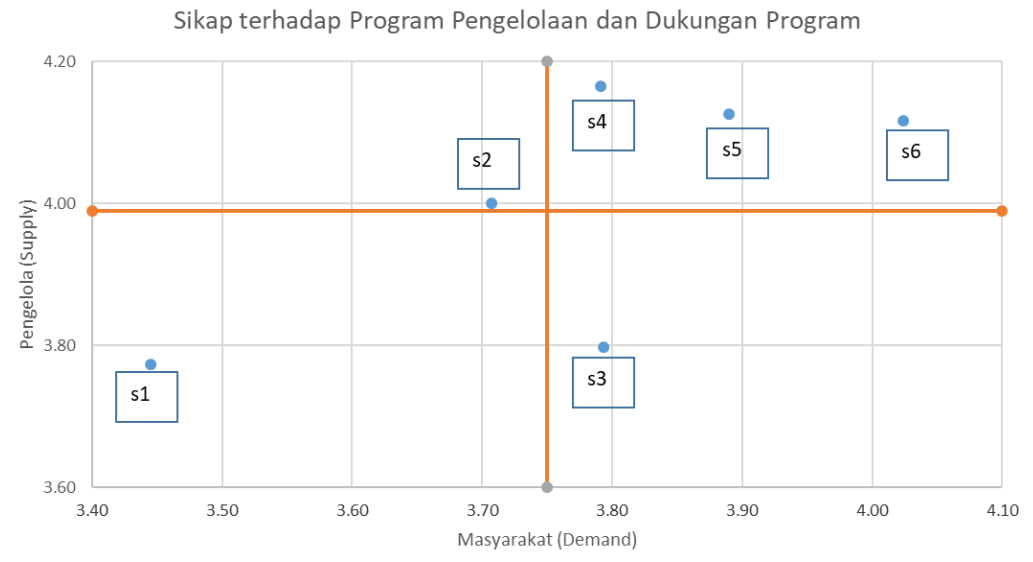

Gambar 3. Analisis Demand-Supply terhadap Sikap

"Sikap terhadap program pembersihan dan penanganan sampah" dan "program optimalisasi pompa air", dan "sikap terhadap dukungan pelaksanaan program" berada pada kuadran I, artinya sikap yang ditunjukan oleh pengelola pada pelaksanaan program ini memberikan dampak positif terhadap masyarakat. Program ini memiliki pelaksanaan yang baik, sehingga perlu dipertahankan. Pada kuadran II terdapat "sikap terhadap program pengerukan waduk". Hal ini menunjukkan bahwa terdapat perbedaan sikap terhadap program pengerukan waduk. Rendahnya sikap masyarakat pada program ini mungkin karena dalam pelaksanaan kurang terlibat.. Pada kuadran III, terdapat "sikap terhadap program pembebasan lahan dan relokasi ke rumah susun", artinya untuk program ini perlu perhatian yang ditingkatkan lagi dari pengelola, sehingga sikap dan dukungan masyarakat terhadap program ini meningkat. Terdapat "sikap terhadap program taman kota" pada kuadran IV, artinya program ini dapat terus dijalankan.

Tingkat Kepuasan terhadap Program Pengelolaan Waduk Pluit

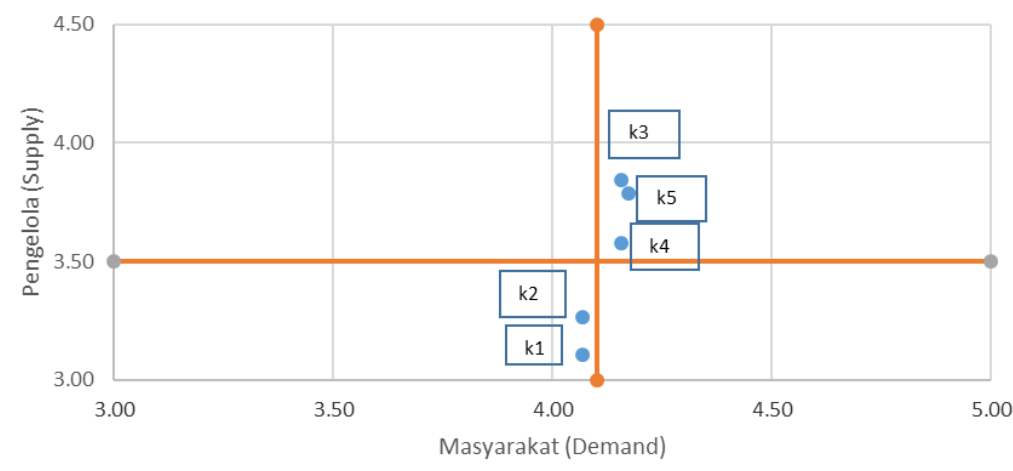

Gambar 4. Analisis Demand-Supply terhadap Tingkat Kepuasan

"Tingkat kepuasan terhadap program taman kota", "program pembersihan dan penanganan sampah" dan "program optimalisasi pompa air", berada pada kuadran I, artinya program ini memiliki pelaksanaan yang sudah baik, sehingga perlu dipertahankan dalam pelaksanaannya. Pelaksanaan dan pencapaian yang dilakukan pada ketiga program ini memberikan tingkat kepuasan yang tinggi baik bagi pengelola maupun bagi masyarakat. Pada kuadran III, terdapat "tingkat kepuasan terhadap program pembebasan lahan dan relokasi ke rumah susun" dan juga terhadap "program pengerukan waduk", artinya untuk kedua program ini perlu perhatian yang ditingkatkan lagi dari pemerintah/ pengelola. Hal ini menunjukkan baik bagi pengelola maupun masyarakat, hasil pelaksanaan dari kedua program ini belum memuaskan. 
Beberapa kebijakan yang dapat diambil selanjutnya berdasarkan pertimbangan hasil penelitian terhadap tingkat pengetahuan, sikap, maupun kepuasan baik masyakarat serta pengelola Waduk Pluit dijabarkan sebagai berikut:

1. Tingkat pengetahuan masyarakat dan pengelola terhadap masalah yang terjadi di Waduk Pluit lebih tinggi dibandingkan dengan tingkat pengetahuan masyarakat maupun pengelola terhadap fungsi waduk. Artinya, informasi terkait masalah lebih diketahui, sehingga pemerintah bersama-sama dengan pengelola harus fokus terhadap upaya penanganan masalah yang terjadi di Waduk Pluit. Selain itu, terdapat sosialisasi yang intens terhadap masyarakat terkait program-program yang dilakukan di Waduk Pluit, serta adanya transparansi yang dilakukan setiap pengelola kegiatan baik transparansi waktu pelaksanaan, transparansi target pelaksanaan, serta transparansi anggaran. Hal ini guna target waktu serta hasil pelaksanaan dapat dimonitor oleh semua pihak, termasuk masyarakat.

2. Sikap dan dukungan yang positif dari masyarakat, menunjukkan bahwa pelibatan masyarakat dalam pelaksanaan setiap program normalisasi Waduk Pluit dapat menjadikan pengelolaan Waduk Pluit berjalan optimal.

3. Tingkat kepuasan yang rendah baik dari pengelola maupun masyarakat terhadap program pembebasan lahan dan relokasi ke rumah susun juga terhadap program pengerukan waduk, menunjukkan bahwa pelaksanaan program ini harus lebih diperhatikan.

4. Bedasarkan analisis supply-demand, tingkat pengetahuan/ persepsi baik pengelola maupun masyarakat masih rendah, seperti pada program pembebasan lahan dan relokasi rumah susun, program pengerukan waduk, dan program pembersihan dan penanganan sampah. Perlu adanya peningkatan kejelasan isi program sehingga pengelola dapat menjalankan program dengan baik, serta peningkatan sosialisasi dan transparansi yang dapat meningkatkan pengetahuan masyarakat terhadap program-program tersebut.

5. Bedasarkan analisis supply-demand, sikap yang masih rendah baik dari pengelola maupun masyarakat adalah terhadap program pembebasan lahan dan relokasi ke rumah susun. Kebijakan yang dapat diambil adalah dengan menerapkan pelaksanaan pembebasan lahan dan proses relokasi masyarakat ke rumah susun dengan lebih transparan.

6. Bedasarkan analisis supply-demand, tingkat kepuasan yang masih rendah baik dari pengelola maupun masyarakat adalah terhadap pembebasan lahan dan relokasi ke rumah susun dan juga terhadap program pengerukan waduk. Program pengerukan waduk harus dilakukan secara transparan dan rutin, sehingga hasil dari pelaksanaan program dapat dirasakan oleh masyarakat.

\section{KESIMPULAN}

Berdasarkan hasil analisis tentang tingkat pengetahuan/persepsi, sikap, dukungan dan kepuasan terhadap pengelolaan Waduk Pluit maka dapat disimpulkan bahwa, tingkat pengetahuan/ persepsi masyarakat dan pengelola terhadap masalah yang terjadi di Waduk Pluit lebih tinggi dibandingkan dengan tingkat pengetahuan masyarakat maupun pengelola terhadap fungsi waduk.Tingkat pengetahuan/ persepsi terhadap program-program normalisasi adalah cukup mengetahui. Sikap dan dukungan positif ditunjukkan baik dari masyarakat maupun pengelola terhadap program normalisasi Waduk Pluit. Tingkat kepuasan yang rendah baik dari pengelola maupun masyarakat terhadap program pembebasan lahan dan relokasi ke rumah susun juga terhadap program pengerukan waduk. Bedasarkan analisis supply-demand, tingkat pengetahuan/ persepsi baik pengelola maupun masyarakat masih rendah, seperti pada program pembebasan lahan dan relokasi rumah susun, program pengerukan waduk, dan program pembersihan dan penanganan sampah. Bedasarkan analisis supply-demand, sikap yang masih rendah baik dari pengelola maupun masyarakat adalah terhadap program pembebasan lahan dan relokasi ke rumah susun. Bedasarkan analisis supply-demand, tingkat kepuasan yang masih 
rendah baik dari pengelola maupun masyarakat adalah terhadap pembebasan lahan dan relokasi ke rumah susun dan juga terhadap program pengerukan waduk.

\section{DAFTAR PUSTAKA}

Adi, S. (2013). Karakterisasi Bencana Banjir Bandang di Indonesia. J.STI, 15(1), 42-51.

Agyaputeri, Kasih, B., \& Rahayu S. (2017). Kajian Kualitas Hidup Masyarakat Waduk Pluit Pasca Relokasi di Rusunawa Muara Baru. Jurnal Pengembangan Kota, 5(1), 17-27. doi: 10.14710/jpk.5.1.17-27.

[BPS Jakarta] Badan Pusat Statistik Jakarta. (2019). Jakarta dalam Angka 2019. Jakarta: BPS.

Dahlan, M. S. (2009). Statistik Untuk Kedokteran dan Kesehatan. Jakarta: Salemba Medika.

Dekiawan, H., \& Subagyo, H. (2018). Simulasi Model SWOT-AHP dalam Penentuan Pilihan Alternatif Strategi Pengembangan Perguruan Tinggi Vokasi D3. Erudio (Journal of Educational Innovation), 5(1), 19-34.

Dina. (2013). Begini Ceritanya tentang Pluit. [internet]. [diacu 2019Agustus5]. Tersedia dari: https://metro.tempo.co/read/456863/begini-ceritanya-tentang-pluit/.

Fachrul, M. F., Rinanti, A., Hendrawan, D., \& Satriawan, A. (2016). Kajian kualitas air dan keanekaragman jenis fitoplankton di perairan waduk pluit jakarta barat. Jurnal Penelitian Dan Karya Ilmiah Lemit, 1(2), 109-120.

Falatehan, A. F. (2016). Analytical Hierarchy Process (AHP) Teknik Pengambilan Keputusan untuk Pembangunan Daerah. Yogyakarta: Indomedia Pustaka.

Ginting, S. (2015). Kajian dan Efektivitas Pengendalian Banjir di DKI Jakarta. [Tesis]. Bandung: Institut Teknologi Bandung.

[Kemendikbud] Kementerian Pendidikan dan Kebudayaan. (2016). Kamus Besar Bahasa Indonesia Online Versi daring: 1.4.10.2-20190521165842. [internet]. [diacu 2019 Agustus 25]. Tersedia dari https://kbbi.kemdikbud.go.id/entri/waduk.

(2016). Kamus Besar Bahasa Indonesia Online Versi daring: 1.4.10.220190521165842. [internet]. [diacu 2019 Agustus 25]. Tersedia dari https://kbbi.kemdikbud.go.id/entri/persepsi.

Kordi, M. G. H. K., \& Tancung, A. B. (2007). Pengelolaan Kualitas Air Dalam Budidaya Perairan. Jakarta: PT. Rineka Cipta.

Lasmana, Y., Wurjanto, A., \& Kardhana, H. (2013). Aplikasi SOBEK Untuk Simulasi Kegagalan Tanggul laut; Studi Kasus Pluit-Jakarta. Jurnal Teknik Hidraulik, 2(2).

Linne, E. R., Suryanto, A., \& Muskananfola, M. R. (2015). Tingkat Kelayakan Kualitas Air Untuk Kegiatan Perikanan di Waduk Pluit, Jakarta Utara. J.maquares, 4(1), 35-45.

Maharani, T., Hardiana, A., \& Mustaqimah, U. (2015). Taman Interaktif di Waduk Pluit Sebagai Ruang Kegiatan Publik Bagi Masyarakat di Jakarta. J.Arsitektura, 13(1).

Nugraha, U. (2015). Hubungan Persepsi, Sikap dan Motivasi Belajar Terhadap Hasil Belajar pada Mahsiswa Pendidikan Olahraga dan Kesehatan Universitas Jambi. Jurnal Cerdas Sifa, $1(1), 1-10$.

Nurhan, K. (2014). Waduk Pluit, Semangat Membangun Jakarta Baru. Jakarta: Kompas.

[Pemprov DKI Jakarta] Pemerintah Provinsi Daerah Khusus Ibukota Jakarta. (2012). Peraturan Daerah Provinsi Daerah Khusus Ibukota Jakarta Nomor 1 Tahun 2012 Tentang Rencana Tata Ruang Wilayah 2030. Jakarta: Pemprov DKI Jakarta.

(2018). Peraturan Daerah Nomor 1 Tahun 2018 tentang RPJMD Provinsi DKI Jakarta Tahun 2017-2022. [internet]. [diacu 2019 Agustus 25]. Tersedia dari https://bappeda.jakarta.go.id/uploads/document/2018-0712/65/65_RPJMD_DKI_Jakarta_2017-2022.pdf.

Prasetijo, R., \& Thalauw, J. J. O. I. (2005). Perilaku Konsumen. Yogyakart: ANDI

Jurnal Manajemen dan Organisas (JMO),

Vol. 12 No. 1 ,

April 2021,

Hal. 21-35

Pratiwi, D. (2014). Analisis Yuridis Normalisasi Waduk Pluit Berdasarkan Peraturan Daerah Khusus Ibu Kota Jakarta Nomor 1 Tahun 2012 Tentang Rencana Tata Ruang Wilayah 2030. Jakarta: Perpustakaan Universitas Trisakti. 
Rahayu, W. M. (2010). Persepsi, Sikap, dan Perilaku Masyarakat Terhadap Kelestarian Hutan (Studi Kasus di Desa Cinagara dan Desa Pasir Buncir Kecamatan Caringin, Kabupaten Bogor, Jawa Barat). [Skripsi]. Bogor: Departemen Manajemen Hutan Fakultas Kehutanan Institut Pertanian Bogor.

Rohmatulloh, \& Winarni, S. (2012). Evaluasi Prioritas strategi SWOT dengan Analytical Hierarchy Process. PROSIDING Seminar Nasional Statistika III: Peranan Statistika di Bidang Pemasaran dalam Pemyusunan Strategi Bisnis. Sabtu, 20 Oktober 2012. Bandung: Universitas Padjadjaran.

Sarwono, S. W., \& Meinarno, E. A. (2009). Psikologi sosial. Jakarta: Salemba Humanika.

Shaw, B. C., Mechenich, L., \& Klessig. (2004). Understanding Lake Data. USA: University of Wisconsin.

Sedyawati, E., Rahardjo, S., Johan, I. M., \& Ohorella, G. A. M. (1987). Sejarah Kota Jakarta 1950 - $1980 . \quad$ Depdikbud. Jakarta. Tersedia pada http://repositori.kemdikbud.go.id/7517/1/SEJARAH\%20KOTA\%20JAKARTA\%201950 -1980.pdf.

Sugiyono. (2015). Metode Penelitian Pendidikan (Pendekatan Kuantitatif, Kualitatif dan R\&D. Bandung: Alfabeta. 